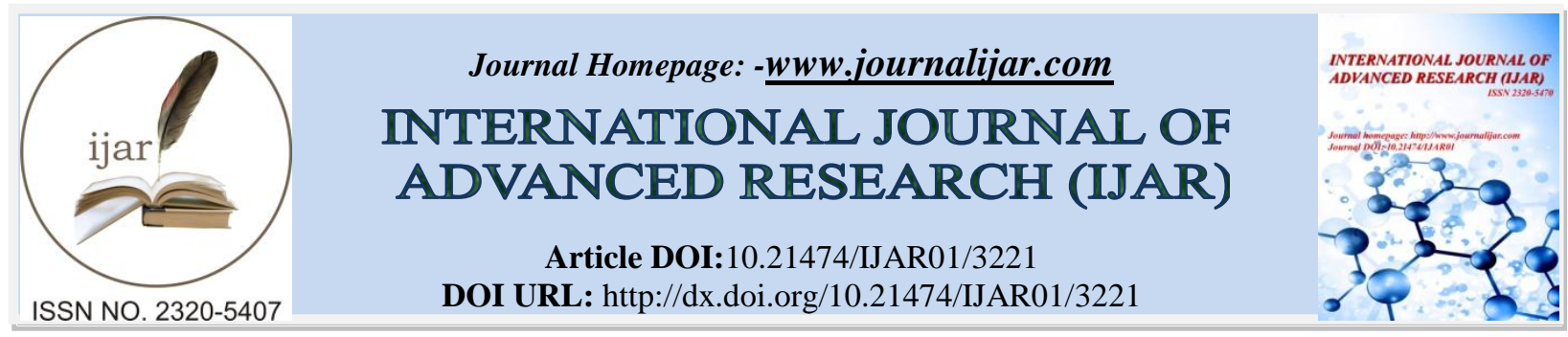

RESEARCH ARTICLE

\title{
LEGAL CERTAINTY OF OWNERSHIP RIGHT FOR UNIT FLATS:A REVIEW ON THE SALE AND PURCHASE AGREEMENT
}

\section{Andi Batari Anindhita}

Graduate School, Hasanuddin University, Jln. PerintisKemerdekaan KM. 10, Tamalanrea, Makassar, South Sulawesi, Indonesia.

\section{Manuscript Info}

Manuscript History

Received: 19 December 2016

Final Accepted: 14 January 2017

Published: February 2017

Key words:-

Flats, Agreements, Contract, Legal Certainty

\begin{abstract}
The concept of home-ownership with a system of co-ownership (condominium) in Indonesia known as the flats. This researchaimsto analyze the legal force of Sale and Purchase Agreement and to reviews the legal protection of buyer for the unit flats. The type of study was juridical-empirical, a study based on library research, as well as field research. The outcomes of the research indicate that the Sale and Purchase Agreement as a basis of unit flats ownership is not evidence that can provide legal certainty for buyers/consumers, because in practice, not carried out in accordance with the Act on Unit Flats. The responsibility of development actors to give legal certainty to buyers of unit flats is the fulfillment of obligation of the development actors with the delivering of freehold title for unit flats. The lack of regulation of concerning the sale and purchase agreement leads to the weak of legal protection for unit flats buyer in obtaining legal certainty for unit flats ownership.
\end{abstract}

Copy Right, IJAR, 2017,. All rights reserved.

\section{Introduction:-}

The1945Constitution of the Republic of Indonesia (hereinafter referred to as "The 1945 Constitution") has provided guarantees to every person to live in prosperity inner and outer, residing and get a good and health living environment and as a basic human need. ${ }^{1}$ The fulfillment of these basic needs become an obligation for the government to provide facilities in the provision of adequate housing for every citizen of Indonesia.

The development of population is increasing overtime it certainly related to the need for the availability of adequate housing. While, available land for housing need never grow. Anticipating the need for the availability of such housing, the government then makes the concept of home ownership with a system of co-ownership (condominium), known as flats. The system of home ownership with the concept of condominium is a solution in the provision of housing, especially in urban areas whose population continues to increase with an effective land use.

The concept of housing, in Indonesia later obtained a legal basis for the establishment of Act No. 16 of 1985 on the Flats was later amendment by Act No. 20 of 2011 on the Flats (hereinafter abbreviated UURS). In the considering of letter "b" UURS stated that the State is responsible for protecting all Indonesian citizens in the implementation of housing through flats eligible for life that is healthy, safe, harmonious and sustainable throughout Indonesia.

Corresponding Author:-Andi Batari Anindhita.

Address:-Graduate School, Hasanuddin University, Jln. PerintisKemerdekaan KM. 10, Tamalanrea, Makassar, South Sulawesi, Indonesia. 
Government's liabilities emphasizes in UURS is certainly not only to ensure the availability of flats eligible, but must be accompanied by the provision of legal certainty over the ownership of the units flats by the owner of the unit flats.

In the context of contract law, the agreement that occurs in the relation of sale and purchase legal creates rights for achievement and obligations for fulfill the accomplishment. According to Christine $\mathrm{Jolls}^{2}$, contractshave traditionally been regarded as means by which individuals may commit themselves to specified courses of conduct. However, a contract is not a means by which the parties collectively may achieve such commitment. Contract law permits parties to modify contractual terms by mutual agreement. ${ }^{3}$ Contracts are individual commitments, but nothing more; both parties' commitments are only as strong as their contracting partners' desire to hold them to their original promises.

Legal certainty in the ownership of flats, especially on unit flats by the owner must be a hope for every owner the flats, so that they can obtain legal protection of ownership, so it can utilize the ownership of flats well. For example, flat owners can ensure their flats to raise capital in business activities. Legal certainty of unit flats ownership can be realized with the issues of flat certificate as proof of ownership legality.Based on Article 1234 of the Indonesian Civil Code, this achievement may be giving something, do something and not do anything. What is something here depends on the parties to a legal relationship, what will be given, what will be done or should not be done. Words "something" can be in the form of material (tangible) and can be in the form of immaterial (intangible). ${ }^{4}$

In the pre-research by the author, the circumstances occurring in at least one flats in Jakarta, ${ }^{5}$ namely Flats "W". Based on preliminary research through interviews ${ }^{6}$ with some buyers/consumers of flats explained that they complained of the legal uncertainty for the ownership of unit flats earned solely on the Sale and Purchase Agreement (hereinafter abbreviated as SPA). Based on their explanation, that since buying unit flats based SPAthe flats in 6 (six) years ago, the development actor do not provide certainty of time on the SPA is conducted in the presence Land Deed Official (hereinafter abbreviated as PPAT) as a basis for rights transfer over the unit flats for them can be done the delivery of Freehold Title on unit flats as the basis for a strong proof of ownership to the buyer/consumer. Though the construction of flats in the tower has been completed, even many of the buyers/consumers are making payments of unit flats in cash or by credit, until the installment is completed but never performed Sale and Purchase Certificate or giving Freehold Title of unit flats had bought.

This situation will conflict with one of the purpose of unit flats ownership as stated in Flats Act, which is about to provide legal certainty in the ownership of flats. ${ }^{7}$ The legal certainty ${ }^{8}$ for flat ownership at least can be used as the basis to be able to take legal actions against unit flats them, as it can easily be resold or can be used as loan collateral in the Bank.

\section{Method of the Research:-}

The type of study was juridical-empirical, a study based on library research, as well as field research.This research was conducted in Jakarta on Flats Development Actors "W", "X", "Y", the Regional Office of the National Land Agency of Jakarta, Jakarta Provincial Governors' Office and the Office of Notary.

The population in this research is the Development Actors/Business Performers on the Flats in Jakarta, Buyer/Consumer of Unit Flats, Head of the Regional Office of the National Land Agency of Jakarta, Jakarta

2 Jolls, Christine. (1997). "Contracts as Bilateral Commitments: A New Perspective on Contract Modification." The Journal of Legal Studies, 26(1): 203-237.

3 Schwartz, Alan, and Robert E. Scott. (2003). "Contract theory and the limits of contract law." Yale Law Journal, 14(2): 541-619.

4 RiduanSyahrani. 1992. SelukBelukdanAsas-asasHukumPerdata, Third edition. Alumni. Bandung. page. 205.

5 Jakarta, the Capital of Indonesia. A research site the author.

6 Interview on 27 February 2016 in Flats "W", CempakaPutih, Jakarta.

7 Adrian Sutedi. 2012. HukumRumahSusundanApartemen. SinarGrafika. Jakarta. page. 198.

8 Kelsen H. (2007). General Theory of Law and State, (Translated bySomardi. TeoriUmumHukumdan Negara). BEE Media Indonesia, Jakarta, page. 16 
Provincial Government and Notary. The technique of sampling was purposive sampling, ${ }^{9}$ by considering that only meets the specific criteria in accordance with the purpose of the research is used as a sample.

The data obtained in this research were primary and secondary data, it will be analyzed qualitatively and presented descriptively, by elaborating, explaining and describing the legal protection is reflected through the legal certainty provided to buyer/consumers of unit flats for unit flats purchases through Sale and Purchase Engagement Agreement.

\section{Results and Discussion:-}

A Review of Sale and Purchase Agreement as Basis for of Unit Flats Ownership:-

The definition and scope of the Sale and Purchase Agreement (SPA) normativelyis not found in the Flats Act. Flats Act is not specifically regulate the characteristics of the SPA, and in fact there is no further explanation of what is meant by the SPAin Flats Act in Indonesia. SPA is only referred to in Article 42 and 43 of Flats Act, as a legal instrument against the sale and purchase of unit flats to the development actors who have not completed all the facilities and the building of flats to be sold it. SPAin Article 42 of Flats Act set conditions on the procedure of sale and purchase of unit flats that unfinished construction namely the seller as development actors can do marketing before construction of flats. Furthermore, in Article 42 paragraph (2) stipulated that in terms of marketing is done before the construction of flats as described in paragraph (1), development actors must have at least 5 (five) things:

$>$ certainty of space allocation;

$>$ certainly rights to land;

$>$ certainty of tenure status of flats;

$>$ permitting the construction of flats; and

$>$ guarantee for construction of flats from insurance corporation.

Then in Article 42 paragraph (3) determined that in terms of marketing is done before the construction of flats completed as referred to in paragraph (2), then everything that is agreed by development actor and/or binding marketing agent as the Sale and Purchase Engagement Agreement (SPA) for the parties.

Based on the analysis of author on the provision of Article 42 paragraph (1), (2) and (3) of Flats Act above, the instrument of SPAin sale and purchase of unit flats cannot just be done, if it does not meet all the requirements specified in the Flats Act. The provisions of Article 42 paragraph (2) of Flats Act are requirements that must be met by development actors before marketing. According to author, the requirement must be met cumulatively; so that the SPAmay have binding force is strong.

Apart from the two article in Flats Act, orders for further guidance on the SPA was not found in Flats Act, so what and how SPAreferred to in new Flats Act, do not have special characters. SPAarrangements prior to the enactment of new Flat Act found in the Decree of the Minister of People Housing No: 11/KPTS/1994 on Guidelines for the Sale and Purchase Engagement of Unit Flats. Decree of the Ministeris declared valid because not been revoked or amendment by new regulations under the provisions of Flats Unit.

In the annex to the Decree of Ministerial provides that the SPA is a sale and purchase agreement by message or preliminary purchase agreement which then will be set forth in the Sale and Purchase Certificate of Unit Flats. Thus, the SPA as a form of agreement on matters agreed between development actors as the seller and the buyer of unit flats that binding formal-juridical on both parties, although the character of SPAtheoretically still at the stage of precontractual or pre-selling contract, because SPA has contained rights and obligations between the purchaser or consumer with development actors/business actor.

However, based on the analysis of literature data, the binding force of SPA is largely determined by the character of SPA provided by Flats Act. This means, the legally binding force of SPA is determined by the fulfillment of the requirements set out in a limited manner in Article 43 paragraph (1) and (2) of Flats Act. Thus, according to the author, although SPA has met the requirements for the validity of an agreement, but if SPA was created not qualify under Article 43 paragraph (1) and (2) of Flats Act, the SPA does not have strong binding legal force.

9 Bambang Sunggono. (2006). MetodologiPenelitianHukum, PT. Raja GrafindoPersada, Jakarta, pages. 44-45 
Theoretically, an agreement on a particular issue that made consciously by those who made it, whether made orally or in writing, that they meet the provisions of Article 1320 of the Civil Code on the validity of the terms of the agreement, then the agreement is binding on the parties. Terms of validity of agreement in question are:

$>$ agreed to those who bound themselves;

$>$ skills of the parties to make an engagement;

$>$ a certain thing;

$>$ alawful cause

The first and second requirement ( $a$ and $b$ ) referred to as the subjective condition because both of those conditions must be met by the subject of the law, while the third and fourth is referred to as objective conditions for these two conditions to be met by the object of the agreement. Differences both requirements associated with nieteg or null and $a b$ initio and vernietigbaar = voidable of an agreement. If the objective requirement in this agreement is not fulfilled, the agreement is null and void or agreement from the beginning has been canceled, the law presumes the agreement never existed. If the subjective requirement is not met then the agreement can be canceled or the whole of the agreement have not been canceled or not the court, the agreement in question was still valid. ${ }^{10}$

In relation to the SPEmade between development actors/businesses actor with buyers/consumers, can be analyzed based on the provisions of Article 1320 of the Civil Code, then the signing of the SPA by the parties as set forth in the SPA between Development Actors in this case Development Actors "W" and "X" with the buyers/consumers, indicating that it has fulfilled the elements agreed for those that bind himself.

Someone said give consent or agreement (toestemming) if he did want what was agreed. Based on the analysis of data from interviews with respondents were 20 (twenty) peoples, all respondents stated that they wanted the signing of SPA. Badrulzaman ${ }^{12}$ explains the definition of agreed as a condition of the will of approved (overeenstemandewilsverklaring) between the parties. The statement of parties offering called bid (offerte), whereas the statement of parties accepting offering called acceptances (acceptatie).

Based on the provision, in relation to the results of interviews by the author ${ }^{13}$ found the conclusion that they consciously have the intention to buy the unit flats which is then signing the deed of SPA, as shown in Table 1.

Table 1:- Data on statement of intent of respondents in SPA on Development Actors "W" and "X" of Flats

\begin{tabular}{|c|c|c|c|c|}
\hline \multirow{2}{*}{ Development Actor } & \multicolumn{2}{|c|}{ Statement of Intent } & Amount & Percentage \\
\cline { 2 - 5 } & Read and Signed & Not read and Signed & & \\
\hline W & 0 & 10 & 10 & $50 \%$ \\
\hline X & 10 & 0 & 10 & $50 \%$ \\
\hline \multicolumn{2}{|c|}{ Total } & 20 & $100 \%$ \\
\hline
\end{tabular}

Source: Primary data, 2016 (Edited)

Data on Table 1 shows that all the respondents on Development Actors "W" claimed that the SPA was signed not read beforehand. Although not read, but the SPA was signed, thenin formal judicial, statement of intent of the parties have stipulated in the SPA, it meaning that the parties have agreed to bind himself in agreement with the intended object of unit flats, although 10 (ten) respondents of flats "W" recognizes that the contents of SPAwere not read, and only informed that the SPAis evidence that the respondent has bought the flats.

Such conditions corresponding to the recognition of the Head of PPPSRS Mr. Be, ${ }^{14}$ that based on complaints from buyers of unit flats on Development Actors "W", they are only required to sign without reading the contents of the

10 SubektiandTjitrosudibio. (2003).KitabUndang-UndangHukumPerdata. Pradnya Paramita. Jakarta. page. 330

11 Data document of SPA between Development Actor/Business Actor "W" with Buyer/Consumer No. 00445 (made under hand) signed on 23 April 2013 in Jakarta (title under hand), and data document of SPA between Development Actor "X" with Buyer/Consumer No. 08, dated 11 July 2013 made in the notary of Fauzah Askar, SH (Notarial deed)

12 RidwanKhairandy. (2004). HukumAlihTeknologi. Modul II. Faculty of Law, Islamic University of Indonesia. Yogyakarta. page. 11.

13 Analysis of questionnaire for 10 (ten) respondent of development actor "W" and 10 (ten) respondent of development actor "X", that distributed on October 2016 in Jakarta. 
SPA in advance, as well as SPApreviously should not be taken home to be studied prior to signature, but development actors "W" only provides an opportunity for buyers/consumers see SPAshortly before signed on the same day.

In such conditions, must all respondents do not understand the contents of the SPA, as well as recognition of the respondents listed in Table 2. However, the development actor "X"of all respondents (100\%) admitted that the SPA was read in advance by the Notary before they are asked to sign it. However, when asked if they understood the contents of the SPA, it turns out there are 2 (two) of 10 (ten) of respondents or $20 \%$ did not understand the details of the SPA, as shown in Table 2.

Table 2:- Data on respondent's knowledge on SPA of flats of development actors "W" and " $\mathrm{X}$ "

\begin{tabular}{|c|c|c|c|c|}
\hline Development actor & $\begin{array}{c}\text { Understand the content } \\
\text { of SPA }\end{array}$ & $\begin{array}{c}\text { Do not understand the } \\
\text { content of SPA }\end{array}$ & Amount & Percentage \\
\hline W & 0 & 10 & 10 & $100 \%$ \\
\hline X & 8 & 2 & 10 & $100 \%$ \\
\hline \multicolumn{2}{|c|}{ Total } & 20 & $100 \%$ \\
\hline
\end{tabular}

Source: Primary data, 2016 (edited)

The data in Table 2 shows that $100 \%$ of respondents in Development Actors "W"do not understand the contents of SPA because it does not read out in advance or no explanation is given by the Development Actors and respondents were only asked to sign it. All respondents (100\%) on the Development Actors "W" just know that with the signing of the SPA, they have obtained flats that would be his/her and understood as his/her own. SPAfor them has been considered as proof of ownership of the flats.

Based on a review of the requirement related to the validity of the binding force agreement SPAas the basis for the acquisition of flats, then all requirements referred to in Article 1320 of the Civil Code are nominally fulfilled. However, when reviewed based on the contents of the SPA, the Development Actors "W" made under hand, tend to weaken the position of the buyer/consumer. Because the deed of SPAhad been prepared in advance or prepared in a standard contract model, so buyers/consumers only sign to the contents of deed. It is recognized by all respondents on Development Actors "W" 10 peoples (100\%) that they are only required to sign the deed of SPA(See Table 1).

It can happen, because in practice, the SPA is an agreement made unilaterally by development actors/businesses actor in the form of raw agreement contain standard clauses, which can certainly allegedly contained clauses that may favor or favor the perpetrators of such development. Clauses in raw agreements can only be made in such a way and can even be made is not clear and firm with the aim to protect the interests of development players from certain obligations, or instead they refrain from clauses that can bind to and guarantee the rights of the buyer or consumers that could potentially harm the buyer or consumer.

In fact, from the principle of the law of treaties (agreement), agreements must be made in good faith. The principle of good faith is a principle known in the law of agreement, more details on the provisions on good faith is governed by Article 1338 paragraph (3) of the Civil Code, that the agreement must be made in good faith. Good faith is also not only refers to the good faith of the parties, but should also refer to the values that developed in the community, because the assessment of a will can be good or bad derived from living law or law in the community. With such meanings are made in good faith as a universal social force that govern social relations between them. ${ }^{15}$

The limited arrangement to the SPAin Flats Act and implemented by Development Actors are not based on the fulfillment of the principles in the agreement and consumer protection, can lead to legal uncertainty and tend to harm the buyer/consumer. While in reality, the SPAis a way of buying and selling of flats which must be carried out by development actors/businesses actor, for giving a great business opportunity and a way of marketing that is more easily attract buyers.

14 Interview on 12 October 2016 in Jakarta.

15 RidwanKhairandy. (2015). KebebasanBerkontrak\&PactaSuntServanda Versus ItikadBaik: Sikap Yang HarusDiambilPengadilan. FH UII Press. Yogyakarta. Page 52. 


\section{Legal Protection against Flats Buyer Based on Sale and Purchase Agreement:-}

In theoretical, legal protection implies a meaning protection derived from the legal provision and/or any laws made by a State or on the basis of the peoples' agreement to regulate the relationship between the individual and the government that is considered to represent the peoples' interests. Relating to the legal protection of buyer/consumer of flats on the basis of SPA may refer to Salim H.S ${ }^{16}$ that the legal protection as an effort or form of service provided by the law to the subject of law and matters became a protected object. In this case, the form of services provided by Flats Act in providing protection for the interests of buyers in the acquisition of flats by using SPAinstrument, so that the buyers of flats can enjoy the rights granted by the law, namely the ownership of flats.

SPA as legal instruments in the process of sale and purchase of flats that regulated in Flats Act expected to be a strong legal instrument as basis for the acquisition of flats, so it can provide legal protection to the buyer/consumer, but it turned out to be based on research results state the expected does not materialize, because SPAapparently not be grounds for them to raise it to the Sale and Purchase Agreements for further obtained the Freehold Title as proof of ownership rights to the flats.

Based on data analysis of questionnaire to 20 (two) twenty respondents from 2 (two) development actor, it turns out all respondents $(100 \%)$ argued that SPAis proof of ownership of flats. On the contrary, they admit that SPAthey have not yet as basis for demanding their rights to obtain legal certainty in the form of Freehold Title that has been bought in cash. That is, until now SPAthey have not been able to be increased to the Certificate of Sale and Purchase henceforth as basis for the issuance of Freehold Title of flats. Such conditions corresponding to the results of an interview ${ }^{17}$ with Mr. A as Legal Staff on Development Actors "W", that SPA of flats from buyers who have paid cannot be processed the Certificate of Sale and Purchase because main certificate on behalf development actor have not been published to date. In addition, the requirements that have been agreed in the SPAthat the signing of Certificate of Sale and Purchase will be made if the flats have been fully developed.

In relation to the reasons given by Mr. A as Legal Staff, by comparing the statement of the Head of Land and Land Registration of BPN Jakarta Andi Tenrisau that Development Actors "W" has not entered a registration application of Freehold Title of flats, so what has been agreed in the SPA that the Certificate of Sale and Purchase will be made if the main Freehold Title of flats has been issued on behalf development actors, not enabling to be realized and it will only be a reason for development actors to evade responsibility. Data from the questionnaire on knowledge about the SPA can be seen in Table 3.

Table 3:- Data on respondents'knowledge on the Position of SPA as proof of ownership of flats

\begin{tabular}{|c|c|c|c|c|}
\hline $\begin{array}{c}\text { Development actor } \\
\text { W }\end{array}$ & $\begin{array}{c}\text { Understand the Position } \\
\text { of SPA }\end{array}$ & $\begin{array}{c}\text { Do not Understand the } \\
\text { Position of SPA }\end{array}$ & Amount & Percentage \\
\hline $\mathrm{X}$ & 0 & 10 & 10 & 100 \\
\hline \multicolumn{2}{|c|}{ Total } & 10 & 10 & 100 \\
\hline
\end{tabular}

Source: Primary data, 2016 (edited)

The data in table 3 shows that the respondents do not understand the position of SPAin Flats Act, because in their understanding, when it had signed the SPAthen they already feel they are receiving legal protection of his/her rights as a buyer of flats. The form of legal protection that they expect is to obtain legal certainty of ownership in the form of Freehold Title of flats. In Flats Act, legal certainty of flats ownership by the issuance of freehold title of flats as proof of ownership of flats. Freehold Title of flats will be strong evidence for the flats owner and can be used as collateral.

Based on the analysis of author, especially against the legal norms that regulate the SPAin Flats Act, it can be concluded that the arrangements of SPAthat are limited in Flats Act cannot provide legal protection to the buyer/consumer, for the arrangement of SPAin Flats Act is only as administrative requirements. While, the position of SPAas proof of buying and selling on flats are not confirmed.

16 Salim HS. (2014). PenerapanTeoriHukumpadaPenelitianTesisdanDisertasi. PT. RajaGrafindo Persada. Jakarta. page. 262

17 Interview on 11 October 2016. 
Based on the results of study found that not all development actors do marketing has completed the administrative requirements set out in Flats Act, as in Development Actors "W". Based on interview with Andi Tenrisau ${ }^{18}$ as Head of Right to Land and Land Registry of National Land Agency Jakarta that the ownership of land for construction of flats by Development Actors "W" is unclear because until now the Development Actors "W" are not yet signed the petition right, Though the requirement of land ownership status for the construction of flats should be clearly defined in Article 43 paragraph (2) of Flats Act.

Buyer/consumer is protected by UUPK particularly concerning the rights of consumers, among others, set forth in Article 4 of the right to obtain compensation and/or reimbursement, if the goods and/or services received are not in accordance with the agreement or not as it should be. In addition, development actors/businesses actor burdened with the obligation under Article 7 UUPK to be good faith in conducting its business activities, as well as provide the correct information, clear and honest about the condition and guarantee of the goods and/or services and explain the use, repair and maintenance.

Clearly, UUPK stipulates the purpose of the enactment of UUPK among others set forth in Article 3 letter (d), to create a consumer protection system contains elements of legal certainty and transparency of information and access to information. However, the provision of Article 3 of UUK does not materialize in the research by the author. Because the data is based on questionnaires to 20 respondents, it turns out all (100\%) of the respondents had paid in cash their flats, but development actors not provide time certainty for the issuance of Freehold Title. In this condition, according to Lili Rasjidi and WyasaPutra, ${ }^{19}$ the legal protection is not able to provided by the law, but legal protection is actually output from the workings of the law believe the theory of interest of fairness, expediency and legal certainty in an effort to provide public services. That is, when the SPAis set as a legal instrument in sale and purchase of flats, then it should have the legal character of the SPAwere made should be more concrete, in order to provide legal certainty.

In theoretical, the form of legal protection is divided into two forms, namely: ${ }^{20}$ First, the protection is preventive.Second, the protection is repressive.Preventive protection is legal protections that are precautionary. Protection provides the opportunity for people to submit his/hercomplaint before a decision the government receives in definitive. So that legal protection is intended to prevent disputes and it great significance for the acts of government that is based on freedom of action. ${ }^{21}$ While the legal protections that are repressive function to complete the event of a dispute.

The government in legislation or policies made should provide solutions in order to provide protection to the buyers/consumers who buy flats and has fulfilled all its obligations as a buyer. Moreover, the nomenclature of SPAare accommodated into new Flats Act is not accompanied by any further settings, according to the authors provide arrangements vagueness that result in the absence of the protection afforded by the State Government in this regard to the buyer of flats. Ideally, sale and purchase based on the SPA can only be done when it has to meet the requirements of Article 42 and Article 43 Flats Act, but the practice many development actors/ businesses actor that conduct development and marketing and selling of flats though not meet all the administrative requirements specified in Flats Act.

In relation to the legal protection provided by the government, the authors argues that arrangements or regulation granted by the government to the buyer/consumer of flats that purchased by sale and purchase agreement do not reflect the absence of legal protection, both preventive and repressive. This is evident from the absence of further regulation of Flats Act that governing specifically the time limit should be observed by development actors/business actors to improve the status of SPAfor subsequent Freehold Title issued on flats.

\section{Conclusions:-}

Sale and Purchase Agreement (SPA) as a basis of flats ownership is not evidence that can provide legal certainty for buyers/consumers, because in practice, not carried out in accordance with the Flats Act. The responsibility of development actors to give legal certainty to buyers of flats is in the fulfillment of obligation of the development

18 Interview on 14 October 2016 at Regional Office of National Land Agency of DKI Jakarta

19 Lili Rasjidiand IB Wyasa Putra. (1993). HukumSebagaiSuatuSistem.RemajaRusdakarya. Bandung. page. 118

20 Philipus M. Hadjon. (1987). PerlindunganHukumBagi Rakyat Indonesia. Bina Ilmu. Bandung. Page 2

21 Salim HS. (2014). Op.Cit. Page 264 
actors with the delivery of Freehold Title of flats after the buyer completes the entire payment and other costs that have been agreed in the SPA. The lack of regulation of the SPAin Flats Act causing the weak of legal protection to the buyer in obtains legal certainty for flats ownership. In relation to the provision of legal protection to the buyer of flats, then the instrument of SPAneeds to be revisited in its existence in Flats Act in order not to become a tool for development actors to ease marketing but ignore the rights of buyer/ consumer to obtain legal certainty.

\section{References:-}

1. Adrian Sutedi. (2012). HukumRumahSusundanApartemen. SinarGrafika. Jakarta.

2. Bambang Sunggono. (2006). MetodologiPenelitianHukum, PT. Raja GrafindoPersada, Jakarta.

3. Jolls, Christine. (1997). "Contracts as Bilateral Commitments: A New Perspective on Contract Modification." The Journal of Legal Studies, 26(1): 203-237.

4. Kelsen H. (2007). General Theory of Law and State, (Translated bySomardi. TeoriUmumHukumdan Negara). BEE Media Indonesia, Jakarta.

5. Lili Rasjidiand IB Wyasa Putra. (1993). HukumSebagaiSuatuSistem.RemajaRusdakarya. Bandung.

6. Philipus M. Hadjon. (1987). PerlindunganHukumBagi Rakyat Indonesia. Bina Ilmu. Bandung.

7. RiduanSyahrani. 1992. SelukBelukdanAsas-asasHukumPerdata, Third edition. Alumni. Bandung.

8. RidwanKhairandy. (2004). HukumAlihTeknologi. Modul II. Faculty of Law, Islamic University of Indonesia. Yogyakarta.

9. RidwanKhairandy. (2015). KebebasanBerkontrak\&PactaSuntServanda Versus ItikadBaik: Sikap Yang HarusDiambilPengadilan. FH UII Press. Yogyakarta.

10. Salim H.S. (2014). PenerapanTeoriHukumpadaPenelitianTesisdanDisertasi. PT. RajaGrafindo Persada. Jakarta.

11. Schwartz, Alan, and Robert E. Scott. (2003). "Contract theory and the limits of contract law." Yale Law Journal, 14(2): 541-619.

12. SubektiandTjitrosudibio. (2003). KitabUndang-UndangHukumPerdata. Pradnya Paramita. Jakarta. 